How to cite: Urzică, A., Huțanu, E., Pricop, C., Mihu-Pintilie, A. (2019) GIS Modeling for Dam Reconstruction. Case Study: Nichiteni Dam, Botoșani County. 2019 "Air and Water - Components of the Environment" Conference Proceedings, Cluj-Napoca, Romania, p. 261-270, DOI: 10.24193/AWC2019_26.

\title{
GIS MODELING FOR DAM RECONSTRUCTION. CASE STUDY: NICHITENI DAM, BOTOȘANI COUNTY
}

\author{
Andrei URZICÄ $\breve{A}^{1}$, Elena HUȚANU ${ }^{1}$ 凹, Claudiu PRICOP ${ }^{2}$ \\ Alin MIHU-PINTILIE ${ }^{1,3}$
}

DOI: 10.24193/AWC2019_26

\begin{abstract}
The study area is located in the northeastern part of the Moldavian Plain and is geologically part of the Eastern European Platform. The Moldavian Plain, from a hydrological point of view, is characterized by a well-represented hydrographic network, but with small and medium flows and a significant number of aquatic accumulations. The storage areas in the Moldavian Plain play a triple role: either they are used for fish or farming purposes, or they are used as efficient flood management structures. In the last decades, the number of these storage areas has seen a dynamic in terms of losing water by clogging and drainage, but also gaining in surface by rehabilitating them. The loss of lenticular water surfaces induces a number of negative effects in terms of the economic structure of neighboring human settlements. From a hydrological point of view, the lack of such areas can lead to devastating effects when floods occur in an area characterized by low rainfall but unevenly distributed and aggressive. This article aims at supporting the importance of achieving and maintaining the storage area functionality in the Volovăt River basin by simulating two situations in order to regenerate the dam in the Nichiteni area. For the analysis of these two situations, the hydrological modeling program, HECRAS v. 5.0.5 and ArcGIS v. 10.2.2 will be used. A first modeling process is to simulate a constant flow under the current conditions of the lack of a dam in the Nichiteni area to highlight the loss of water volume that would hypothetically be stored in the long run and accessible to various economic activities. The second model is the reconstruction of the dam in the same settlement accompanied by the simulation of the lake's retention capacity in the event of a flood.
\end{abstract}

Keywords: dam reconstruction, flood damage, Nichiteni dam, HEC-RAS

\section{INTRODUCTION}

The importance of dams and implicitly the generation of aquatic accumulation upstream to the dams has been observed since antiquity when such structures were

\footnotetext{
${ }^{1}$ Alexandru Ioan Cuza University of Iasi, Faculty of Geography and Geology, Department of Geography, Bd. Carol I 20A, 700505, Iasi, Romania. E-mail: andreurzica@gmail.com hutanu.elena@yahoo.com

2 Water Basin Administration Prut-Bârlad, Str. Theodor Văscăuțeanu, 10, 700462, Iași claudiu.pricop@gmail.com.

${ }^{3}$ Alexandru Ioan Cuza University of Iasi, Interdisciplinary Research Department, Field Science, St. Lascar Catargiu 54, RO-700107 Iaşi, Romania mihu.pintilie.alin@gmail.com.
} 
built for the use of the water resource in domestic or agrarian activities. Gradually, other possibilities for using dams and aquatic accumulations have been identified.

They can have both agricultural purposes (use of water for irrigation, zootechnics, etc.) (Mettetal, 2018), or they may have a tourism purpose (recreation areas) (Nezirović, 2016), or they can have an industrial purpose (fish farming, hydropower, water supply) (Hecht et al., 2019) or can be used to regulate minor river beds in order to diminish the negative effects when a flood event can have a devastating impact on human society.

There are about 45,000 large dams (over $15 \mathrm{~m}$ in height) and over 800,000 smalls (with a storage capacity of about $7,000 \mathrm{~m}^{3}$ ) worldwide.

The dams represent the most important hydrotechnical structure, so they have been studied by many researchers at both national level (Romanescu et al., 2011a) and internationally (Mohammad Amin, 2018; Yu-jun et al., 2018; Wu et al., 2018; Marchetti et al., 2018; Lempérière, 2018), highlighting their economic and administrative importance, but also the effects of the lack of such works in the propagation of the flood wave (Kourgialas and Karatzas, 2000; Spencer, 2004; Moel et al., 2009; Romanescu and Nistor, 2011; Romanescu et al., 2011b; Romanescu and Stoleriu, 2013, 2014; Ghanbarpour and Mohseni, 2014).

In Romania 2,617 dams are listed in the Romanian National Register of Dams (in Romanian - Registrul National al Barajelor din Romania - REBAR), of which 2,087 are made for water storage, 231 industrial waste deposits, and 299 are special hydro-technical works.

Of the total number of dams, 372 are classified into two important categories, A (exceptional importance) and B (special importance), while 2,245 belong to C (normal importance) and $\mathrm{D}$ (minor importance) categories.

The first mention of the construction of a dam in the Moldavian region dates back to 1450-1550, when dams were built to store a volume of water useful for water supply to the population, but also for use in agriculture. The use of dams as a flood defense tool began in 1960, when the Izvorul Muntelui Lake from Neamt county was put into service.

Before 1989, there were many lakes in Romania formed especially upstream to a $\mathrm{C}$ or D dam for fishing purposes and for water storage. Most of these dams were located, in particular, in the plains where the risk of droughts was very high.

The dam taken as case study is located on the Volovăt River, near Nichiteni settlement, Botosani County (Fig.1). From a geomorphologic point of view, the hydrographic basin of the Volovăţ River is part of the Moldavian Plain. The area of the lake is 28.1 ha and the height of the dam is $3 \mathrm{~m}$. The purpose of this dam was to store water for periods of drought as well as for fish farming. Currently, the dam is no longer functional, being destroyed.

The present study aims at carrying out a flood simulation in the dam's location area using two scenarios, both of them performing a flood simulation using a highresolution Digital Elevation Model - DEM (LiDAR with a resolution of $1 \mathrm{~m} / \mathrm{pixel}$ ). The first scenario is developed in the current context - the lack of the dam, while the second scenario is to carry out a flood simulation with the same parameters, but 
this time by reconstruction of the dam. The creation of these two scenarios aims at identifying the retention capacity of the lake near Nichiteni area, but also to make a comparison of the affected areas (Jonkman, 2008).
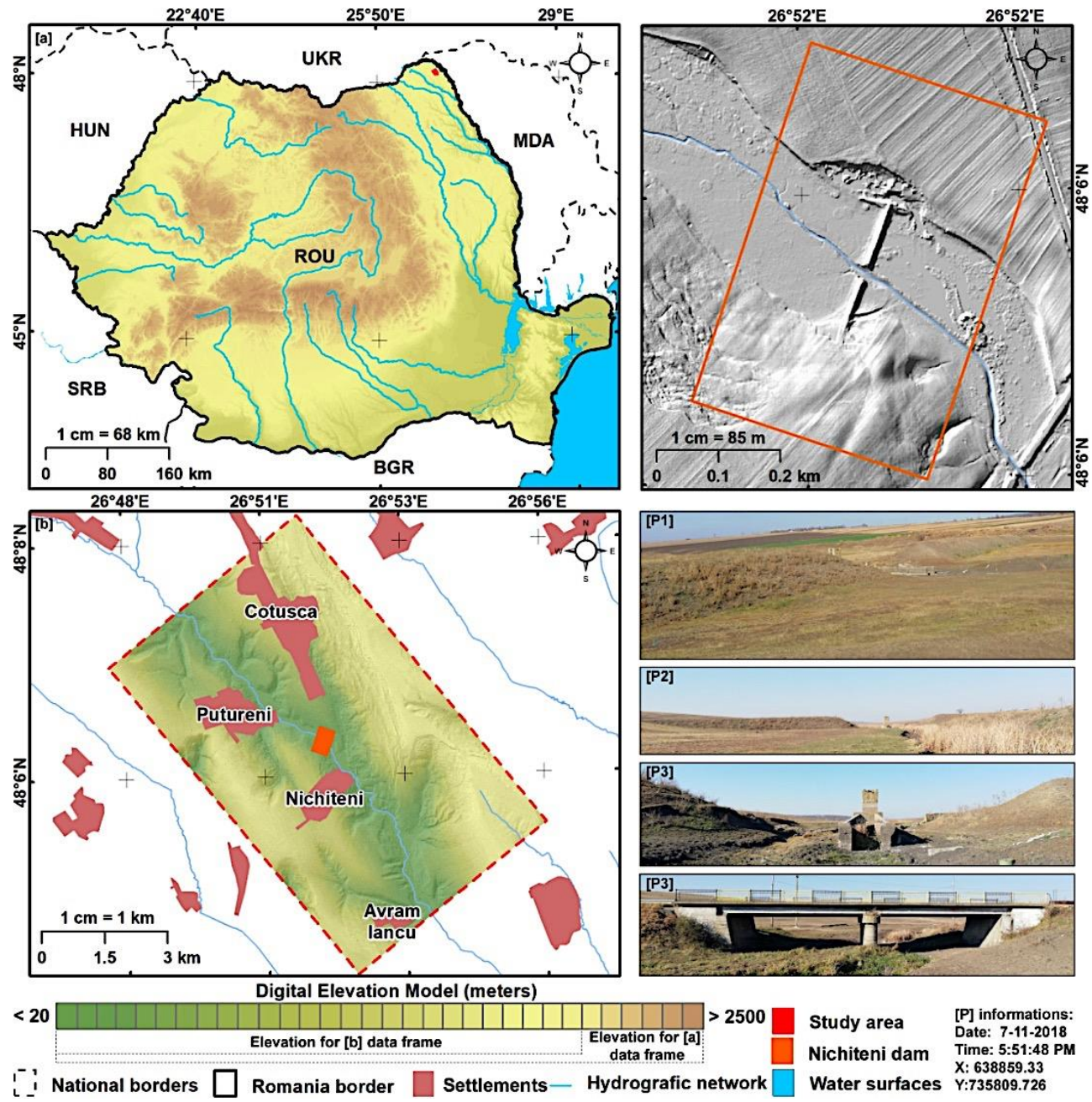
$\begin{array}{ll}\text { Study area } & {[P] \text { informations: }} \\ \text { Date: } 7-11-2018\end{array}$ Nichiteni dam Time: 5:51:48 PM X: 638859.33 Water surfaces $\mathrm{Y}: 735809.726$

Fig. 1. Geographical location of the study area

\section{DATA AND METHODS}

\subsection{Data used}

For the reconstruction of the dam and the running of the two scenarios, a highresolution Digital Elevation Model was needed. Thus, a numerical model of the LiDAR type with a resolution of $1 \mathrm{~m} /$ pixel was used. The data used was made available by the Prut-Bârlad Basin Water Administration, Iaşi. 


\subsection{Methods}

The methodology of the present study was divided into two stages. The first stage was the generation of a DEM (Marks and Bates, 2000) and the digital reconstruction of the dam. Based on the files with the .tif extension obtained from the Prut-Barlad Basin Water Administration, but also based on the methodology presented in Figure 2 , the tif files have been merged and the dam has been mapped.

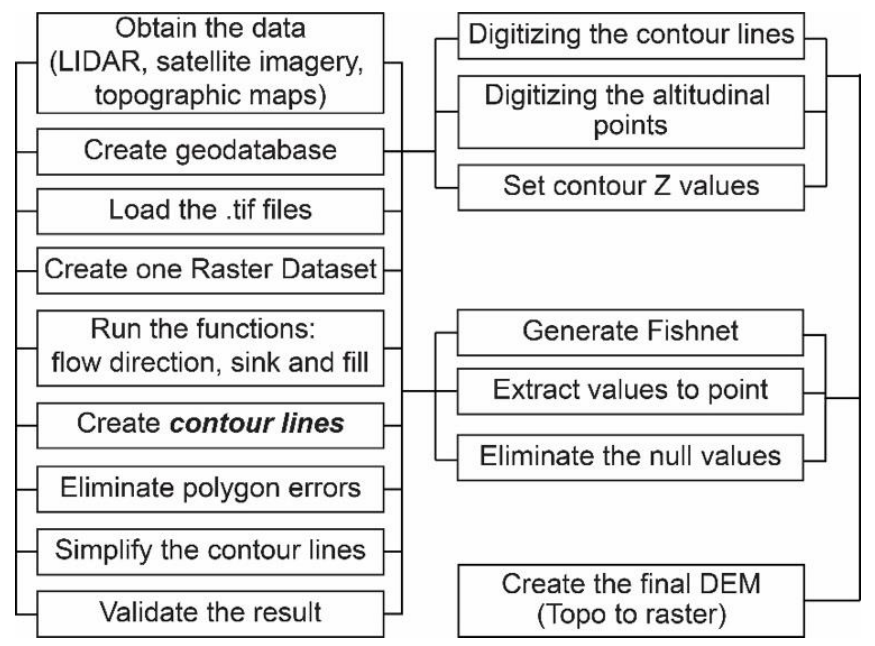

Fig. 2. Methodological workflow needed for the generation of a Digital Elevation Model (DEM) and the digital reconstruction of the dam

The result was a DEM with a spatial resolution of $1 \mathrm{~m} / \mathrm{pixel}$. Based on the DEM, the dam near Nichiteni was virtually reconstructed (Fig. 3).
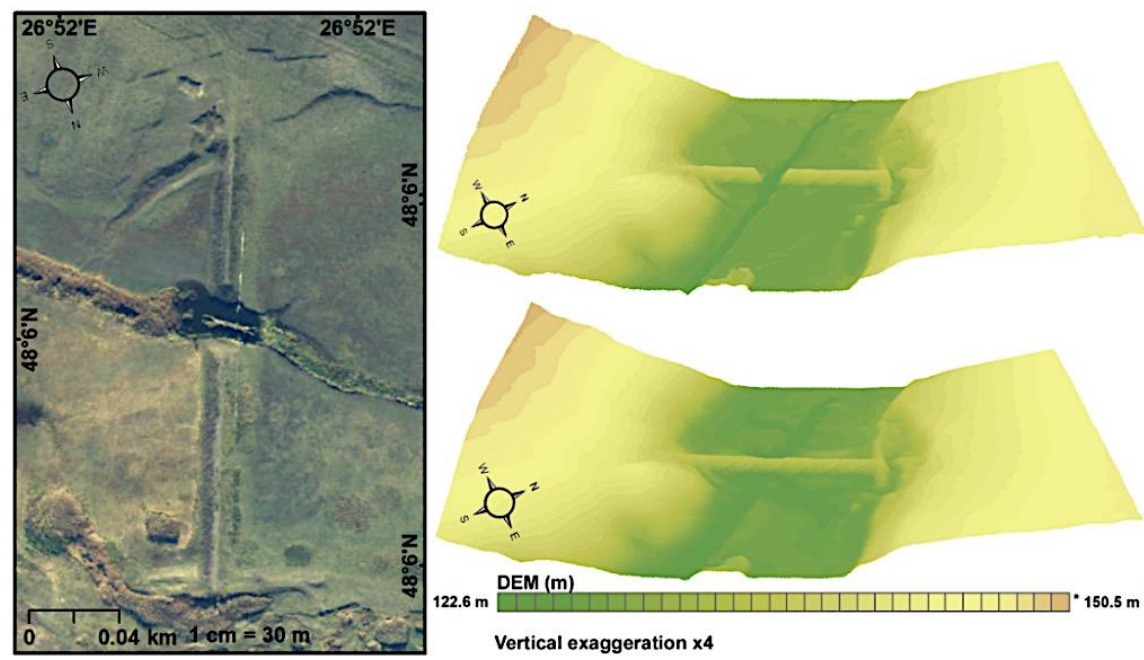

Fig. 3. 3D view of the dam before and after the digital reconstruction 
The second step was to simulate the two scenarios. The work stages to obtain the flood extent were divided into 3 steps: pre-processing, processing and postprocessing (HEC-RAS User's Manual 2016, Urzica et al., 2018, Ghindoanu et al., 2018) (Fig. 4). In the pre-processing step all the vector layers necessary for the floodrun were generated (river, riverpaths, cutlines, storage area). Based on the numeric model, the fields created for each layer were filled in. Several attributes were included, such as: length, hydro-id, station, reach, banks, left/right length, channel length, max elevation, min elevation, volume data.

The next step was to export the previously generated layers to the HEC-RAS program to enter roughness and flow coefficient information for flood simulation without the dam. In case of flood simulation with the reconstructed dam, the connection between the course of the river and the lake created upstream to the dam was made. In both cases, a steady flow simulation with a subcritical mode and a maximum flow rate of $100 \mathrm{~m}^{3} / \mathrm{s}$ was chosen. The flow rate was calculated using the Weibull's (1.1) and Person III (1.2) formulas.

$\mathrm{Pi}=\mathrm{i} /(\mathrm{n}+1) * 100$

where: $\quad \mathrm{Pi} \%$-the probability of the occurrence of a measured flow;

where: Pit the probability of the occurrence of a measured flow,

i-the order number of the flow rate; $n$-the total number of string terms;

$\mathrm{Qp} \%=\mathrm{Qmed}^{*}\left(1+\mathrm{Cv}^{*} \Phi \mathrm{p} \%\right)$

where: $\quad$ Qp - insurance flow rate; Qmed - average flow rate;

$\mathrm{Cv}$ - the coefficient of variation;

$\Phi p \%$ - ordinates of the insurance curve for $\mathrm{Cv}=1$.

The last step consisted in generating the flood raster by exporting the result from the HEC-RAS environment to the ArcGIS environment.

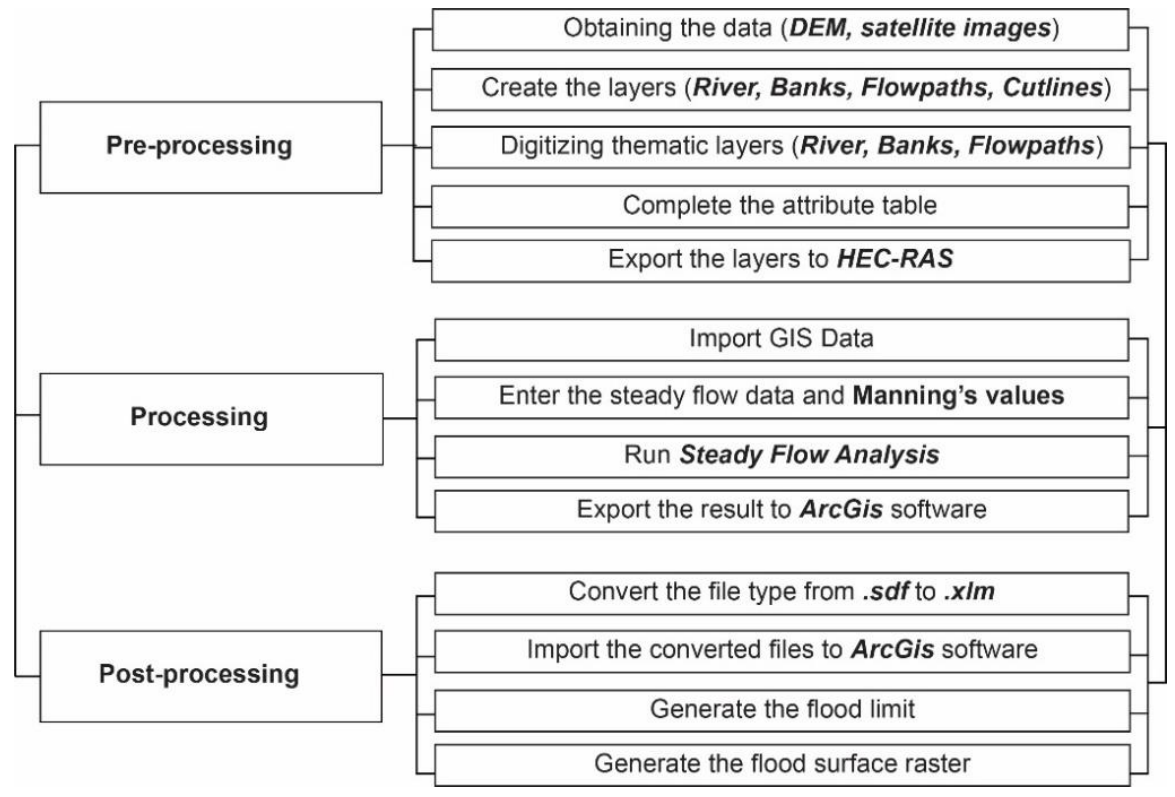

Fig. 4. Methodological workflow to run a simulation in HEC-RAS software 


\section{RESULTS AND DISCUSSIONS}

Analyzing the results of the two simulated scenarios, the construction of the dam near Nichiteni would result in the storage of $550,000 \mathrm{~m}^{3}$ of water in the modelled flood event, which would lead to a considerable decrease in flooded areas downstream of the dam.

In the case of the first simulated situation, the one in which the dam was destroyed, the flooded area amounts to 142.8 ha, out of the total floodplain of 155 ha. The flooded area is $92.12 \%$ and the maximum water level is $300 \mathrm{~cm}$ (Fig. 5).

In the case of the second situation, the one in which the dam is rebuilt, the flooded area is $105.8 \mathrm{ha}$, which represents $68.2 \%$ of the floodplain of the analyzed sector. The maximum water level is $250 \mathrm{~cm}, 50 \mathrm{~cm}$ less than the first scenario.

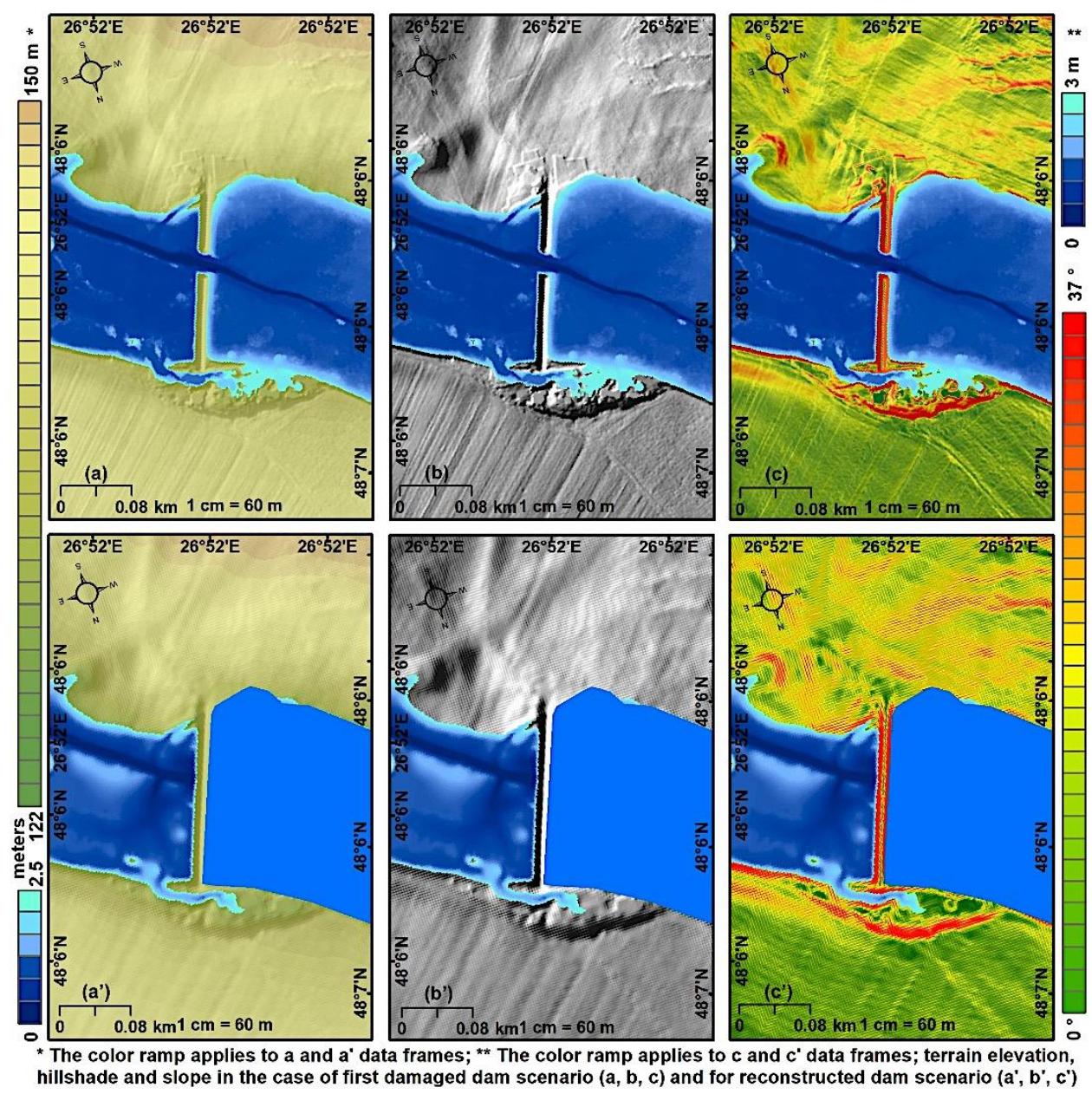

Fig. 5. Flood depth before and after the reconstruction of the dam near Nichiteni settlement 
In terms of land use categories, they were digitized on the basis of ortho images. For both scenarios, the only affected category was given by pasture. The rugged terrain and the active presence of geomorphological processes prevented the construction of dwellings near or within the flooded area of the studied sector.

The differences between the flooded areas for the two scenarios can be seen in Figure 6. In the case of reconstructed dam, the affected area is 37 ha smaller.
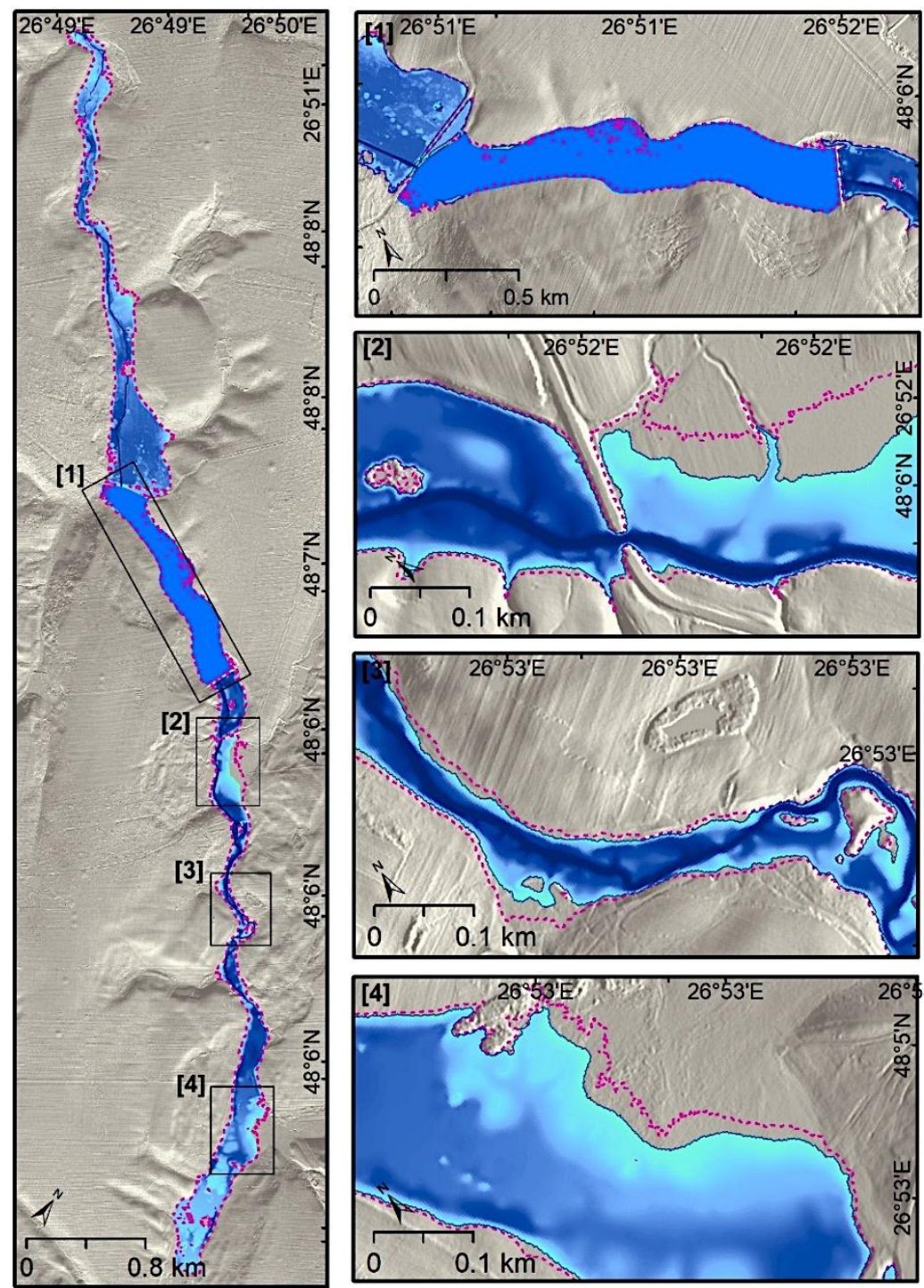

\begin{tabular}{l}
0.5 \\
\hline
\end{tabular}

Storage area

Flood boundary with reconstructed dam

Fig. 6. Differences of flood boundary between the two situations simulated 


\section{CONCLUSIONS}

The present study aimed at highlighting the importance of hydrotechnical structures on rivers, especially embankment works and water storage areas, with case study on the destroyed dam near Nichiteni.

Two scenarios were simulated, in the first scenario a flow of $100 \mathrm{~m}^{3} / \mathrm{s}$ was run, under the current conditions, of the lack of the dam. The second scenario implied the running of the same flow $\left(100 \mathrm{~m}^{3} / \mathrm{s}\right)$, but with the alteration of the Digital Terrain Model, by reconstructing the dam at an altitude of $3 \mathrm{~m}$. Thus, a water storage area of 28.1 ha was generated upstream.

Due to the drought and consequently the lowering of the groundwater level, the reconstruction of the dam near Nichiteni settlement would lead to the storage of a water volume of $550,000 \mathrm{~m}^{3}$ that can be used especially in agricultural activities. Also, the reconstruction of the dam protects downstream a surface of 37 ha in the case of a flow of $100 \mathrm{~m}^{3} / \mathrm{s}$, which is a flow with $1 \%$ exceeding probability.

\section{REFERENCES}

1. Ghanbarpour M.R., Mohseni S.M. (2014). Floodplain inundation analysis combined with contingent valuation: implications for sustainable flood risk management. Water Resour Manage, 28, 2491-2505.

2. Ghindoanu B.V., Hutanu E., Urzica A. (2018). The GIS modelling of the terrain favorability for the placement of constructions in the areas with hydrogeomorphological risk. Geobalcanica 4nd International Scientific Conference. DOI: http://dx.doi.org/10.18509/GBP.2018.03.

3. Hecht J.S., Lacombe G., Arias M.E., Thanh D.D., Piman T. (2018), Hydropower dams of the Mekong River basin: A riview of their hydrological impacts. Journal of Hydrology, 568, 285-300. DOI: https://doi.org/10.1016/j.jhydrol.2018.10.045.

4. US Army Corps of Engineers. Hydrologic Engineering Center, HEC-RAS River Analysis. User's Manual, 2016.

5. Jonkman S.N., Vrijling J.K., Vrouwenvelder A.C.W.M. (2008). Methods for the estimation of loss of life due to floods: a literature review and a proposal for a new methods. Nat Hazards, 46, 353-389.

6. Kelman I., Spencer R. (2004). An overview of flood actions on buildings. Eng Geol, 73(3-4), 297-309.

7. Kourgialas N., Karatzas G. (2000). Flood management and a GIS modelling method to assess flood-hazard areas - a case study. Hydrol Sci J, 56, (2), 212-225.

8. Lempérière F. (2017). Dams and Floods. Engineering, 3(1), 144-149. DOI: https://doi.org/10.1016/J.ENG.2017.01.018.

9. Marchetti N., Curci A., Gatto M.C., Nicolini S., Mühl S., Zaina D. (2018). A multi scalar approach for assessing the impact of dams on the cultural heritage in the Middle East and North Africa. Journal of Cultural Heritage. DOI: https://doi.org/10.1016/j.culher.2018.10.007.

10. Marks K. and Bates P. (2000). Integration of high-resolution topographic data with floodplain flow model. Hydrol Process, 14, 2109-2122. 
11. Mettetal E. (2018). Irrigation dams, water and infant mortality. Evidence from South Africa. Journal of Development Economics, 138, 17-40. DOI: https://doi.org/10.1016/j.jdeveco.2018.11.002.

12. Moel H., Van Alphen J., Aerts J.C.J.H. (2009). Flood maps in Europe - methods, availability and use. Nat Hazards Earth Syst Sci, 9, 289-301.

13. Mohammad Amin Hariri-Ardebili (2018), Risk, Reliability, Resilience $\left(\mathrm{R}^{3}\right)$ and beyond in dam engineering: A state-of-the-art review. International Journal of Disaster Risk Reduction 31. DOI: https://doi.org/10.1016/j.ijdrr.2018.07.024.

14. Nezirović S. (2016) Revitalization of degraded areas of the Tuzla basin and forming artificial lakes in the function of tourism development. Air and Water Components of the Environment. DOI: 10.17378/AWC2016_31.

15. Romanescu G., Stoleriu C., Romanescu A.M. (2011a). Water reservoirs and the risk of accidental flood occurrence. Case study: Stanca-Costesti reservoir and the historical floods of the Prut River in the period July-August 2008, Romania. Hydrol Proces, 25(13), 2056-2070.

16. Romanescu G., Jora I., Stoleriu C. (2011). The most important high floods in Vaslui river basin - causes and consequences. Carpath J Earth Environ Sci, 6(1), 119-132.

17. Romanescu G., Nistor I. (2011b). The effects of the July 2005 catastrophic inundations in the Siret River's Lower Watershed, Romania. Nat Hazards, 57, 345368.

18. Romanescu G., Stoleriu C. (2013). Causes and effects of the catastrophic flooding on the Siret River (Romania) in July-August 2008. Nat Hazards, 63, 1351-1367.

19. Romanescu G., Stoleriu C. (2014). An inter-basin backwater overflow (the Buhai Brook and the Iezer reservoir on the Jijia river, Romania. Hydrol Process, 28, 3118 3131.

20. Urzica A., Mihu-Pintilie A., Hutanu E., Ghindaoanu B.V., Albu L.M. (2018). Using GIS methods for modelling exceptional flood events in Baseu River basin, NE Romania. Geobalcanica 4nd International Scientific Conference. DOI: http://dx.doi.org/10.18509/GBP.2018.51

21. Wu L.Z., Deng H., Huang R.Q., Zhang L.M., Guo X.G., Zhou Y. (2018). Evolution of lakes created by landslide dams and the role of dam erosion: A case study of the Jiajun landslide on the Dadu River, China. Quaternary International. DOI: https://doi.org/10.1016/j.quaint.2018.08.001.

22. Yu-jun Y., Zhou Y., Song J., Shanghong Z., Cai Y., Yang W., Zhifeng Y. (2018), The effects of cascade dam construction and operation on riparian vegetation. Advances in Water Resources, DOI: https://doi.org/10.1016/j.advwatres.2018.09.015. 
